Maurice A. Deane School of Law at Hofstra University Scholarly Commons at Hofstra Law

Hofstra Law Faculty Scholarship

3-12-2019

\title{
Tried and True: Fair Use Tales for the Telling
}

Sarah E. McCleskey

Hofstra University

Courtney L. Selby

Maurice A. Deane School of Law at Hofstra University

Follow this and additional works at: https://scholarlycommons.law.hofstra.edu/faculty_scholarship Part of the Intellectual Property Law Commons

\section{Recommended Citation}

McCleskey, S. E. \& Selby, C., (2019). Tried and True: Fair Use Tales for the Telling. Journal of Copyright in Education and Librarianship, 3(1), 1-27. https://doi.org/10.17161/jcel.v3i1.9754

This Article is brought to you for free and open access by Scholarly Commons at Hofstra Law. It has been accepted for inclusion in Hofstra Law Faculty Scholarship by an authorized administrator of Scholarly Commons at Hofstra Law. For more information, please contact lawcls@hofstra.edu. 


\section{$J$ () Journal of Copyright in E L Education and Librarianship}

JCEL is published by Clemson University Press ISSN 2473-8336 | jcel-pub.org

Volume 3, Issue 1

Tried and True: Fair Use Tales for the Telling

Sarah E. McCleskey \& Courtney Selby

McCleskey, S. E. \& Selby, C., (2019). Tried and True: Fair Use Tales for the Telling. Journal of Copyright in Education and Librarianship, 3(1), 1-27. https://doi.org/10.17161/jcel.v3i1.9754

(C) 2019 McCleskey and Selby. This open access article is distributed under a Creative Commons AttributionNonCommercial-ShareAlike 4.0 International https:// creativecommons.org/licenses/by-nc-sa/4.0/ 


\title{
Tried and True: Fair Use Tales for the Telling
}

\author{
Sarah E. McCleskey, Hofstra University \\ Courtney Selby, Maurice A. Deane School of Law at Hofstra University
}

Correspondence concerning this article should be addressed to: Sarah

E. McCleskey, Head of Resource and Collection Services, Hofstra

University Library, Sarah.E.McCleskey@Hofstra.edu and Courtney

Selby, Associate Dean for Information Services, Director of the Law Library, and Professor of Law at the Maurice A. Deane School of Law, Hofstra University, Courtney.L.Selby@Hofstra.edu.

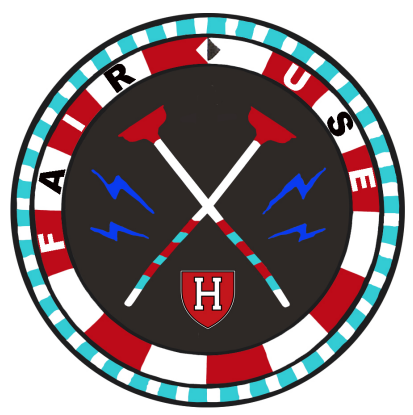

On Thursday, March 1, 2018, the Harvard Library Office for Scholarly Communication hosted "Tried and True: Fair Use Tales for the Telling," a one-day program celebrating Harvard's Fifth Anniversary of Fair Use Week. Leading fair use scholars and practitioners shared their stories and engaged in lively discussion about the powerful and flexible fair use provision of the Copyright Act and its applications. Topics included treatment of the fair use doctrine in recent jurisprudence, conflicts over the use of visual works in remixes and mash-ups, academic work and social commentary, filmmaking, controlled digital lending practices in libraries, software preservation, and more. This article discusses the examples and ideas presented during the program and offers resources for further study in the application of fair use.

Keywords: Intellectual property, copyright, fair use 


\section{Tried and True: Fair Use Tales for the Telling}

On Thursday, March 1, 2018, the Harvard Library Office for Scholarly Communication hosted "Tried and True: Fair Use Tales for the Telling," a one-day program celebrating Harvard's Fifth Anniversary of Fair Use Week. Leading fair use scholars and practitioners shared their stories and engaged in lively discussion about the powerful and flexible fair use provision of the Copyright Act and its applications. The program was made possible through the support of the Knight Foundation.

Kyle K. Courtney, the Copyright Advisor for Harvard University working out of the Office for Scholarly Communication and the founder of Fair Use Week, welcomed a roomful of enthusiastic attendees to the beautiful Knafel Center at the Radcliffe Institute for Advanced Study. To kick off the celebration, Courtney announced the creation of a new award to be given annually during Fair Use Week: The Fair Use Week Founders Award. This award will be given to an individual for the highest level of dedication in the service of Fair Use Week, and as a true friend, scholar, and leader in the promotion of fair use.

The inaugural recipient was a critical player in the early stages of Fair Use Week: Pia M. Hunter. Hunter originally proposed a week celebrating fair use on the Fair Use Allies listserv in 2013. ${ }^{1}$ She is a librarian and was formerly the head of Reserve/Media and Microforms, and later, Copyright and Reserve Librarian and Visiting Assistant Professor at the University of Illinois at Chicago. Once she discovered her enthusiasm for copyright, fair use, and the law, she enrolled in law school at the University of Illinois. Currently Hunter serves as research and instruction librarian and teaching assistant professor at the Albert E. Jenner, Jr. Memorial Law Library, University of Illinois College of Law.

Courtney then launched the day's program with an outline of a Knight Foundation grant Harvard received to explore gaps and opportunities for enabling the sharing of questions related to copyright and fair use: "Can I Fair Use It? Crowdsourcing Fair Use Knowledge." The grant was a specialized Knight News Challenge Prototype project, which not only supported the crowdsourcing effort, but also helped fund the Fair Use Week Fifth Anniversary Symposium itself.

The grant was built from a familiar premise: that misunderstandings and myths surrounding fair use can have cultural, artistic, commercial, scholarly, educational, and free speech implications. Perhaps, however, technology, outreach, and education could solve this problem and stamp out the myths and misunderstandings.

1. Hunter also had the foresight to purchase the domain name fairuseweek.org, preserving it for future celebrations. 
Courtney worked with Jack Cushman from the Harvard Library Innovation Lab and Berkman Klein Center, and Katie Ott, a Copyright Fellow and now law librarian at Stanford Law School, to create the proposed solution to this fair use problem.

A group of 30 copyright experts (lawyers, librarians, archivists, law professors, deans, and technologists) participated in the prototype project, which used rapid technology (software and text messaging) to solicit yes or no answers to real-life fair use scenarios. The project had high participation and very few drop-outs. A few initial questions had uniform agreement (100\% yes or no). More difficult scenarios received a range of responses but still resulted in a majority opinion as to whether a use was fair. Courtney shared an example of a scenario from the project to give a sense of the type of questions used. In the hypothetical, a fan of the Lord of the Rings books decides to write a Web series based on the characters created by Tolkien. While the stories in the series are completely original, the style and tone are similar to Tolkien's, the universe operates similarly, and the characters behave consistently with Tolkien's characters. While there was some difference of opinion among the experts, a majority responded that the Web series would be a fair use. The project advances the idea that broad access to fair use expertise could enable laypersons to quickly measure risk and make more informed fair use decisions.

Knight has generously extended the grant an additional year. Courtney is hoping to refine the software and text system to streamline usage. Additionally, he is looking to expand the scope of experts to see if a rotating pool of fair use expertise could maintain the crowdsourcing system throughout the year. Combining this with new tools for fair use education and outreach, Courtney hopes to see a new, advanced crowdsourcing model in place for the benefit of the public in 2019.

\section{Keynote}

Keynote speaker Kenneth Crews (introduced as "the smiling face of fair use in the United States"!) envisioned a surprise 40th birthday party for Section 107 of The Copyright Act (see Figure 1). ${ }^{2}$ During his address, he discussed some of the unexpected aspects of the development of the fair use doctrine during the past 40 years. Crews outlined four different notions of a surprise (starting with "BOO!!") and applied two of them to explore fair use. He noted that a surprise can be something unexpected ("The Twist"), or something that was foreshadowed and probably could or should have been predicted (“Duh!”). 


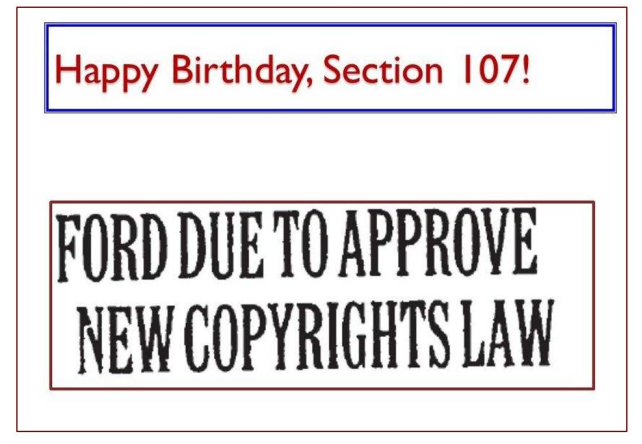

Figure 1. Slide from Crews's presentation, featuring the newspaper headline announcing President Ford's expected approval of The Copyright Act.

There have been several such surprises in the development of the fair use doctrine. One twist is found in the line of decisions holding that the use of whole works can, in appropriate circumstances, be fair use. Crews cited several examples. In the Swatch Group ${ }^{3}$ case, the Second Circuit Court of Appeals held that "[i]n the context of news reporting and analogous activities... the need to convey information to the public accurately may in some instances make it desirable and consonant with copyright law for a defendant to faithfully reproduce an original work rather than transform it." In Bill Graham Archives v. Dorling Kindersley Ltd., ${ }^{4}$ the court held that reproduction of whole concert posters in a book was fair use, where the purpose of the book was biographical and the posters were included as historical artifacts significantly reduced in size. These factors, together with the transformative nature of the work, were found to constitute fair use. ${ }^{5}$ Crews cited a similar finding from Warren Publishing Co. v. Spurlock, ${ }^{6}$ in which the inclusion of cover artwork from out-ofprint magazines in a biography and retrospective of the artist's work was found to be fair. ${ }^{7}$ Finally, he showed some of artist Richard Prince's works, complete reproductions of photographs incorporated into large mixed-media works, a number of which were found to be fair use in Cariou v. Prince (See Figure 2). ${ }^{8}$

3. Swatch Grp. Mgmt. Servs. Ltd. v. Bloomberg, L.P. 742 F.3d 17, 28 (2d Cir. 2014).

4. 448 F.3d 605 (2d Cir. 2006).

5. Id. at 615 .

6. 645 F. Supp. 2d 402 (E.D. Pa. 2009).

7. Id. at 415 .

8. 714 F.3d 694 (2d Cir. 2013). 

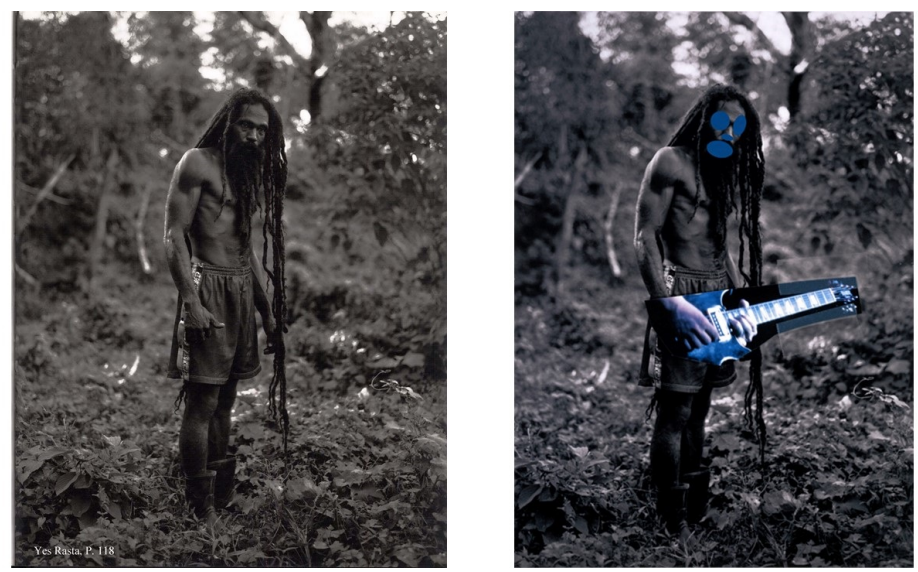

Figure 2. (left) Original photograph from Yes Rasta (p. 118), by Patrick Cariou, 2000, Brooklyn, NY: powerHouse Books. Copyright [2000]. (right) Collage entitled Graduation. Reprinted from Cariou v. Prince, Appendix, 714 F.3d 694 (2d Cir. 2013). Retrieved from http://www.ca2.uscourts.gov/docs/opn1197/11-1197apx.html. Copyright [2008] by Richard Prince.

Another twist has been the receding importance of the second of the four factors articulated in Section 107 (the nature of the copyrighted work). ${ }^{9}$ Courts have not placed emphasis on whether a work is "creative" or "factual" in the same way that they have emphasized distinctions in the other three factors. In Campbell v. Acuff-Rose Music, Inc., ${ }^{10}$ the parody case involving the use of Roy Orbison's "Oh, Pretty Woman," the Supreme Court held that a parody of a creative work may be a fair use. The distinction between creative works and factual works was of little value in the court's analysis, as any work could potentially be the object of a parody. Another landmark case in which the nature of the copyrighted work was of little significance to the fair use analysis is Authors Guild v. Google, Inc. ${ }^{11}$ In holding that Google's scanning of entire works was not infringing, the District Court for the Southern District of New York noted that " $[\mathrm{t}]$ he second factor has rarely played a significant role in the determination of a fair use dispute."12 The Supreme Court denied certiorari. ${ }^{13}$
9. 17 U.S.C. $\$ 107(2)(2012)$.
10. 510 U.S. 569 (1994).
11. 804 F.3d 202 (2d Cir. 2015).
12. Id. at 220 .
13. Authors Guild v. Google, Inc., 804 F.3d 202 (2d Cir. 2015), cert. denied, 136 S. Ct. 1658 (2016). 
Crews also discussed the surprise twist of the "Expansion of Self-Change." He offers the development of Creative Commons licensing ${ }^{14}$ as an example of this trend. Some creators and authors of copyrighted works (e.g. photographs, scholarly publications, datasets, etc.) wish to retain some of the rights afforded by copyright, while simultaneously wishing to allow others to use their works in specified ways. Rather than working to alter copyright law, creators have turned to licensing to change the landscape of ownership and use. Creative Commons licensing allows copyright holders to specify the rights they retain, while clarifying the uses others may make of their work, engaging in self-change on a work-by-work basis. Some museums have also chosen to add Creative Commons licenses to their images of public domain works and to their own photographs of collections and works in which there is clearly room for the museum to claim a copyright. London's National Portrait Gallery and the Metropolitan Museum of Art are just two examples of museums that are moving away from strict copyright statements toward Creative Commons licensing for more flexibility in apportioning rights. ${ }^{15}$

The uptick in open access publishing initiatives is yet another example of self-change. There has been a groundswell of authors, particularly in the area of scholarly publication, choosing to forego traditional copyright agreements with publishers, and instead opting to engage in open access publication. Advocates cite an increase in the value of works that are freely accessible. ${ }^{16}$

Crews next addressed surprises that were perhaps foreshadowed, although they were developments he suggests were absolutely predictable ("Duh!"). These include the marginalization of formal guidelines for those making use of copyrighted works, a move toward integration of the four factors in judicial analysis of fair use claims, and a scarcity of litigation beyond a few cases involving parties with extraordinary financial resources.

14. Creative Commons, https://creativecommons.org/ (last visited July 25, 2018).

15. For museum statements on the use of creative commons licensing, see

https://www.npg.org.uk/collections/search/use-this-image.php?mkey=mw02238 [https://perma.cc/TN2Y-GZBU] and https://www.metmuseum.org/blogs/digitalunderground/2017/open-access-at-the-met.

16. Steve Lawrence, Free Online Availability Substantially Increases a Paper's Impact, 411 NATURE 521 (2001); Chawki Hajjem et al., Ten-Year Cross-Disciplinary Comparison of the Growth of Open Access and How It Increases Research Citation Impact, IEEE Data(base) Engineering Bull., Dec. 2005; James M. Donovan \& Carol A. Watson, Citation Advantage of Open Access Legal Scholarship, 103 LAW LIBR. J. 553 (2011); James M. Donovan, Carol A. Watson \& Caroline Osborne, The Open Access Advantage for American Law Reviews, 97 J. PAT. \& TRADEMARK OFF. SOC'Y 4 (2015). 
He first discussed the marginalization of formal guidelines. Although the classroom copying guidelines provided by the Copyright Office, reproduced in Circular $21,{ }^{17}$ are frequently integrated into policy at educational institutions, they have been rejected by courts. ${ }^{18}$ The Conference on Fair Use (1998) never found support among the various stakeholders. Rights holders found the proposed guidelines too permissive, while users of copyright content found them too restrictive. ${ }^{19}$ Codes of best practices have been more widely accepted as resources but have not replaced the four-factor analysis. ${ }^{20}$

Another predictable development in the law has been the move away from evaluation of four discrete factors in judicial opinions in favor of an analysis that integrates the factors, examines the relationship among the factors based on the facts, or focuses only on individual factors. In Nation Enterprises, ${ }^{21}$ the court identified the fourth factor, the effect of the use upon the potential market, as the most important factor in evaluating fair use, stating that " $[t]$ his last factor is undoubtedly the single most important element of fair use."22 In Campbell v. Acuff-Rose, ${ }^{23}$ the first factor clearly drove the court's analysis and decision. Crews posited that the recent proliferation of decisions relying on transformative use is accelerating this move away from analyzing the four factors separately. ${ }^{24}$

For the last "surprise," Crews remarked on the scarcity of litigation surrounding fair use, particularly in the educational environment. He cited the Google Books ${ }^{25}$ case, the related HathiTrust ${ }^{26}$ case, and the Georgia State ${ }^{27}$ case as high-stakes exceptions to the rule. Georgia State has had a significant impact on library and university core services, and the circumstances surrounding the ongoing litigation have both librarians and university administrators poised for further change. This case represents a

17. United States Copyright Office, Reproduction of Copyrighted Works by Educators and Librarians (August 2014), https://www.copyright.gov/circs/circ21.pdf [https://perma.cc/NF6T-TLCV].

18. Cambridge Univ. Press v. Patton, 769 F.3d 1232 (11th Cir. 2014).

19. U.S. Patent and Trademark Office, Final Report to the Commissioner on the Conclusion of the Conference on Fair Use (November 2018), www.uspto.gov/sites/ default/files/documents/confurep_0.pdf [https://perma.cc/JF45-FUCH].

20. For further information regarding codes of best practices, see The Center for Media \& Social Impact (CMSI) at American University's School of Communication at http://cmsimpact.org/codes-of-best-practices/ (last visited July 25, 2018).

21. Harper \& Row, Publishers, Inc. v. Nation Enters., 471 U.S. 539 (1985).

22. Id. at 566.

23. Campbell v. Acuff-Rose Music, Inc., 510 U.S. 569 (1994).

24. Judge Pierre Leval's landmark article, Toward A Fair Use Standard, 103 HARV. L. REV. 1105-36 (1990), sparked a shift in judicial discourse emphasizing the importance of the transformativeness of the work in a fair use analysis.

25. Authors Guild, Inc. v. Google, Inc., 804 F.3d 202 (2nd Cir. 2015).

26. Authors Guild, Inc. v. HathiTrust, 755 F.3d 87 (2nd Cir. 2014).

27. Cambridge Univ. Press v. Patton, 769 F.3d 1232 (11th Cir. 2014). 
culmination of several years of aggressive tactics by the Association of American Publishers (AAP) to protect copyrighted content used for educational purposes. In the mid-2000s, AAP issued complaints to a number of academic libraries that offered electronic reserve systems based on their inclusion of copyrighted material. After receiving the complaints, several universities created new policies with language approved by AAP to avoid further action. ${ }^{28}$

Despite the attention Georgia State has received, cases focusing on educational use of copyrighted material are few and far between. Crews pointed out some reasons for this paucity. From a rightsholder's perspective, litigation is expensive, time consuming, and can result in negative publicity. Moreover, the risk of an adverse ruling may serve as a deterrent to filing a claim. Where claims have been filed by rightsholders, some institutions have avoided litigation by entering into settlement agreements. Additionally, opportunities for licensing content have expanded and many institutions elect to pay for the security of a license rather than engaging in behavior that might actually be fair use. Finally, the Copyright Act provides specific protections for some educational uses and for libraries and archives under Sections 108 and $110 .{ }^{29}$ Those who use the protections to their benefit avoid actions that might otherwise give rise to litigation.

In closing with a flourish of showmanship, Crews treated the audience to a moment of song in celebration of fair use with his own parody of the sentiment from a 1965 Hedgehoppers Anonymous song (See Figure 3). He also suggested a few possible directions this area of law may take. Self-change initiatives like those described above are likely to grow. While collective licensing may continue to offer solutions for some types of use, there are many instances in which collective licensing falls short. Ephemera, books from publishers who have gone out of business without transferring their rights, accidental use, and a host of other situations fall outside the reach of collective licensing. It is likely that application of the fair use doctrine will grow in these areas. There is also steady pressure to develop collective solutions that may facilitate the use of materials that would otherwise be covered by fair use but cannot be reached by collective licensing. That continued pressure may give rise to practices that serve as alternatives to fair use. The shape these theories and practices take may offer yet another round of surprises to explore.

28. For coverage of the circumstances surrounding the agreements, see Andrea L. Foster, Despite Skeptics, Publishers Tout New 'Fair Use' Agreements With Universities, Chronicle of Higher Education (January 17, 2008), https:// www.chronicle.com/article/Despite-Skeptics-Publishers/114446 and Andrew Albanese, E-reserve reached under duress? Publishers influence new guidelines from three universities, Library Journal, Feb. 15, 2008, at 20.

29. See note 2, supra. 


\begin{tabular}{|l|}
\hline \multicolumn{1}{|c|}{ It's Fair Use Week! } \\
\hline $\begin{array}{l}\text { Congress gave us Factors Four, } \\
\text { Opening a narrow door, } \\
\text { And brightening the sky! } \\
\text { It's Fair Use Week! } \\
\text { Courts have found a way to give } \\
\text { Parody a way to live } \\
\text { So Simpsons never die! }\end{array}$ \\
\hline
\end{tabular}

Figure 3. Slide from Crews's presentation, offering his own Fair Use Week parody of the sentiment in the song "It's Good News Week," recorded by Hedgehoppers Anonymous in 1965.

\section{Litigation and Fair Use, the Last 15 Years}

Following the keynote address, attendees were treated to a panel of three experts, each of whom shared professional experiences and reflections. Dan Booth of Booth Sweet, LLC, Christopher Bavitz of the Harvard Law School Cyberlaw Clinic, and Laura Quilter of the University of Massachusetts, Amherst Libraries, focused on copyright litigation and fair use over the last 15 years.

Dan Booth began the presentation by discussing three recent copyright conflicts involving mash-ups. ${ }^{30}$ The mash-ups at the center of the first two conflicts involved the combination of existing cartoon strips with language from another source. The first was "This Charming Charlie," a Tumblr blog that went viral in 2013. ${ }^{31}$ The graphic designer, Lauren LoPrete, remixes images of Charles Schulz's Peanuts cartoons with lyrics from The Smiths (See Figure 4). As Luke O'Neil described it in Esquire, "Charlie Brown was Morrissey before Morrissey: put upon, isolated, eternally frowning and frumping. Perhaps that's why the two have made for such a delightful match..."32

30. The term mash-up is often used interchangeably with the term remix in the context of copyright law. Lawrence Lessig's work in this area, including his book Remix: Making Art and Commerce Thrive in the Hybrid Economy (Penguin Press 2008), both reflects on and continues to inspire scholars and artists to explore the practice of taking elements from two or more sources and combining them to create new works.

31. This Charming Charlie, http://thischarmingcharlie.tumblr.com (last visited July 25, 2018).

32. Luke O'Neil, Proof Charlie Brown and Morrissey Are Really the Same Person, Esquire (Aug 15. 2013), https://www.esquire.com/entertainment/music/ a24306/charlie-brown-the-smiths/ [https://perma.cc/58F3-GC7H]. 


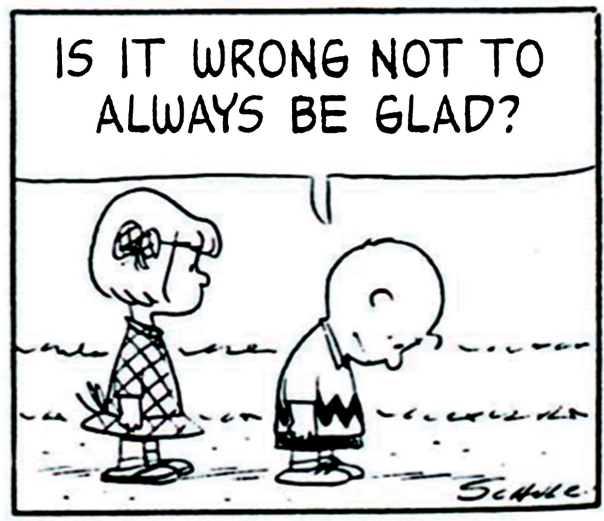

Figure 4. Image from This Charming Charlie [blog], by L. LoPrete, Retrieved from http://thischarmingcharlie.tumblr.com/.

LoPrete received takedown notices and letters from Universal Music, rightsholder for The Smiths' lyrics. Tumblr removed several of the cartoons, but restored them after Booth wrote a letter outlining how LoPrete's parodic mash-ups were perfect examples of transformative fair use. ${ }^{33}$ Booth also showed a screenshot from a Morrissey zine True to You, wherein Morrissey commented that he was "delighted and flattered" by the use of the lyrics. ${ }^{34}$ With Morrisey's stated approval of LoPrete's work on public display, Universal Music declined to take further steps toward litigation.

Another popular Tumblr blog, "Calvin and Muad'Dib,"35 mixes Bill Watterson's beloved comic strip with Frank Herbert's classic science fiction tale Dune (See Figure 5). The creator, who goes only by the name Joe, began his project in early 2012 and almost immediately received Digital Millennium Copyright Act (DMCA) takedown notices. Watterson has typically been staunchly opposed to licensing or merchandising Calvin and Hobbes content. However, in this case Watterson and "Joe" made a formal agreement and licensed the material. Booth pointed out that the mash-up is likely fair use, but that the license shows respect for the creator. Quoted in a Barnes \& Noble Sci-Fi-Fantasy blog, Joe said

33. Letter to Tumblr from Booth Sweet, LLP, (Sept. 20, 2013),

http://thischarmingcharlie.tumblr.com/post/62086118078 [https://perma.cc/39HEJB3X].

34. While the original Web site is no longer available, the Internet Archive has

preserved a copy of the site from the date of the original post at https://

web.archive.org/web/20170423173549/http://true-to-you.net/

morrissey_news_131006_01 (last visited July 25, 2018).

35. Calvin \& Muad'Dib, http://calvinanddune.tumblr.com/ (last visited July 25, 2018). 
"We worked out a licensing deal where I could continue to make comics in the way I intended, and the Calvin and Hobbes lawyers could be ensured that abuse of Bill Watterson's original works would not occur." 36 "Calvin and Hobbes: (C) and ${ }^{\mathrm{m}}$ Bill Watterson, used with permission" appears on every comic on the Tumblr blog.

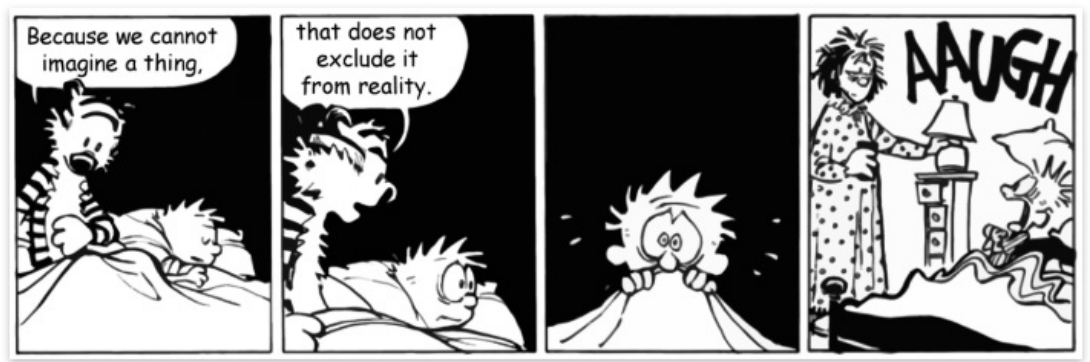

Because we cannot imagine a thing, that does not exclude it from reality.

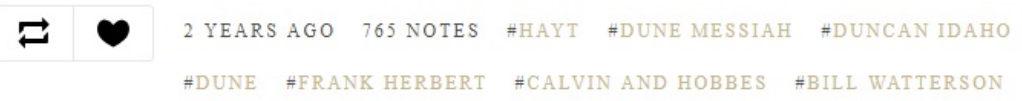

$\#$ COMICS

Calvin and Hobbes: (C) and ${ }^{\mathrm{T} M}$ Bill Watterson, used with permission. Available at www.gocomics.com.

Figure 5. Cartoon from Calvin and Muad'Dib [blog], by Joe. Retrieved from http://calvinanddune.tumblr.com/. Copyright [2015].

Booth wrapped up his presentation with a discussion of an ongoing case. The lawsuit was brought in November 2016 by Dr. Seuss Enterprises; it alleged both copyright and trademark claims against ComicMix for a crowd-funded book project titled Oh, the Places You'll Boldly Go!, an amalgamation of Star Trek and Dr. Seuss (See Figure 6). ${ }^{37}$ In December 2017, Judge Janis Sammartino denied a motion to dismiss the suit. ${ }^{38}$ ComicMix argued that their work is a transformative parody. ${ }^{39}$

36. How One Mashup Artist Got Legal Permission to Pair Calvin \& Hobbes with Dune, Barnes \& Noble Sci-Fi and Fantasy Blog (Feb. 19, 2016), https:// www.barnesandnoble.com/blog/sci-fi-fantasy/how-one-mash-up-artist-got-legalpermission-to-pair-calvin-hobbes-with-dune/ [https://perma.cc/RAF8-AEDE]. 37. Complaint, Dr. Seuss Enterprises, L.P. v. ComicMix LLC, No. 3:16-cv-02779 (S.D. Cal., filed Nov. 10, 2016).

38. Dr. Seuss Enterprises, L.P. v. ComicMix LLC, No. 3:16-cv-02779 (S.D. Cal., Dec. 7, 2017) (order denying motion to dismiss).

39. Motion to Dismiss, Dr. Seuss Enterprises, L.P. v. ComicMix LLC, No. 3:16cv-02779 (S.D. Cal., Dec. 19, 2016). 
However, Seuss Enterprises countered that the work is derivative rather than transformative and may cause market harm for the original (See Figure 7). ${ }^{40}$

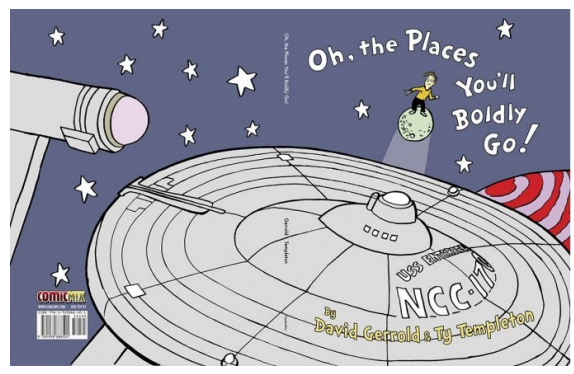

Figure 6. Cover art from Oh, the Places You'll Boldly Go!, by D. Gerold and T. Templeton, 2016, Norwalk, CT: ComicMix.

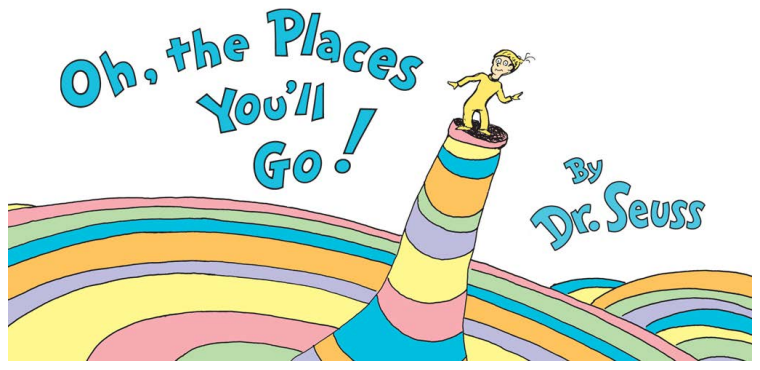

Figure 7. Cover art from Oh, the Places You'll Go!, by T. Geisel, 1990, New York, NY: Random House. Copyright [1990].

In offering these three examples of litigation surrounding mash-ups, Booth demonstrated the range of approaches seen in resolving copyright infringement disputes in which one party asserts that they have made a fair use of existing work to create a new and different work. Transformative fair use can be acknowledged and applauded by the original work's creator, as in the Charming Charlie work, an amicable agreement can be reached between the original creator and the person who later makes a fair use of the content, as in the "Calvin and Muad'Dib" example, or the parties can turn to the courts for a decision as to whether the use is fair.

40. Complaint, Dr. Seuss Enterprises, L.P. v. ComicMix LLC, No. 3:16-cv-02779 (S.D. Cal., filed Nov. 10, 2016). 
Moving from fair use in visual art to fair use in audio material, Christopher T. Bavitz, WilmerHale Clinical Professor of Law at Harvard Law School, discussed fair use litigation in music and sound recordings over the past fifteen years. He began by discussing the impact of the 2005 case, Bridgeport Music, Inc. v. Dimension Films. ${ }^{41}$ In Bridgeport, the group N.W.A. was sued for copyright infringement after they sampled a two-second guitar chord from a song written and recorded by Funkadelic. Despite the fact that the sample was brief, lowered in pitch, and looped in the N.W.A. song, the court held that the use was a violation of copyright. The decision is significant because it established that there is no fair use (or de minimis use) when sampling. The court argued that with a sound recording, the copyright owner has exclusive right to duplicate the work; any usage of any section of a work, regardless of length, would be in violation of copyright unless the copyright owner gave permission. ${ }^{42}$ In its decision, the court advised: "Get a license or do not sample. We do not see this as stifling creativity in any significant way."43

Bavitz then moved to the radio host Michael Savage's copyright infringement complaint against the Council on American-Islamic Relations (CAIR). Savage sued CAIR in late 2007, claiming that the group violated his rights by illegally publishing quotes and audio excerpts from his Savage Nation show in a letter-writing campaign to get advertisers to boycott the program. The Electronic Frontier Foundation and the law firm of Davis Wright Tremaine LLP filed a motion for judgment on the pleadings, asking the Court to dismiss the lawsuit because CAIR's conduct was clearly protected by the First Amendment and the fair use doctrine. In July 2008, the Court granted CAIR's motion, agreeing that CAIR's use of Savage's copyrighted radio excerpts was a protected fair use under copyright law. "Assuming all of plaintiff s allegations are true, the Court finds that the majority of the four fair use factors, including the most important factors, weigh in favor of defendants. Accordingly, the Court finds that fair use applies, and GRANTS defendants' motion for judgment on the pleadings as to plaintiff s copyright infringement claims as a matter of law." ${ }^{4}$ Bavitz

41. 410 F.3d 792 (6th Cir. 2005).

42. Id. at 801 .

43. Id. at 801

44. Savage v. Council on American-Islamic Relations, Inc., No. 3:07-cv-06076-SI, 13

(N.D. Cal. Jul. 25, 2008). While this decision was not reported in the Federal

Supplement, the full text of the opinion is available at https://www.eff.org/files/

filenode/savagevcair/savagecair-opinion.pdf [https://perma.cc/D8Y2-ZRFT]. 
noted the interesting juxtaposition between Bridgeport, where the court found no room for de minimis use of sound recordings in music sampling, and the holding in Savage in which excerpts from sound recordings used for purpose of criticism were found to be fair use.

Taking his review into international territory, Bavitz suggested we consider the implication of embracing models of ownership in intellectual property based in moral rights or concepts of fair dealing. Moral rights refer to the legal framework developed around the idea that creators have a special relationship with their creations, including the notion that an author's interest in her own work is more than simply financial. ${ }^{45}$ Fair dealing is a legal doctrine used in several commonlaw countries which provides specific exceptions to copyright protection and permits the use of copyrighted works that fit within those exceptions. ${ }^{46}$ As we consider uses of materials that cross international boundaries, including recent mass digitization projects, there may be wisdom in exploring not only whether a use may be fair under U.S. law, but whether a use may also be in alignment with a theory of moral rights or articulations of fair dealing in foreign and international law. Where uses may be lawful and fair under American copyright law, but perhaps less clearly lawful under international law, Bavitz noted that some have suggested geo-blocking content to keep it from appearing in jurisdictions where it may contravene copyright law.

Following Bavitz's discussion of fair use litigation in sound recordings and implications of fair use in an international context, Laura Quilter finished the panel with a discussion of the complexities for librarians and educators in trying to teach users how to apply copyright law without giving legal advice. For librarians, particularly those who are also licensed attorneys, there is an important distinction between giving legal advice and providing access to the law or guidance in understanding it. Quilter, Copyright and Information Policy Librarian at the University of Massachusetts Amherst, outlined how we might use case law to help people understand how to apply the law, either by providing a rule of thumb (a quick practice rule) or by attempting to offer an understanding of the law. She noted that both approaches can be difficult in practice.

45. For a detailed discussion of moral rights in intellectual property, see Mira T. Sundara Rajan, Moral Rights: Principles, Practice and New Technology (Oxford University Press 2011). Chapter 4 of this work focuses specifically on moral rights in the international copyright regime.

46. For a thoughtful comparison of fair use in the United States and fair dealing in Canada and the United Kingdom, see Giuseppina D'Agostino, Healing Fair Dealing?A Comparative Copyright Analysis of Canada's Fair Dealing to U.K. Fair Dealing and U.S. Fair Use, 53 MCGILL L. J., 309 (2008). 
Quilter pointed to the difficulties of providing rules of thumb and noted that many areas of law do not have simple guidelines or bright-line rules. In explaining the first of the four factors to be considered in fair use, it is not possible to provide a definitive list of purposes that will determine whether a use is fair. Commercial use is not always "unfair," and non-profit use is not always fair. While jurisprudence on transformative use continues to develop, significant uncertainty remains as to whether a particular use will be considered transformative and whether transformative use alone is enough to constitute fair use. As Crews noted earlier in the day, formal guidelines proffered to date have been rejected by the courts and have found little support among practitioners. At the same time, best practice recommendations cover limited uses and do not take the place of a complete four-factor fair use analysis. Those charged with providing information about and access to copyright law find themselves in this complex context.

Quilter suggested that some practices, such as indexing and creating metadata, are always acceptable from a fair use perspective. Advisors can feel confident in saying that use of copyrighted material for parody and critique tilts strongly toward a finding of fair use. However, there remain many substantive questions that are complex, if not impossible, to explain to a layperson without crossing into the role of offering legal advice. How should we direct those who seek definitive answers about the limits of personal use copies? What is an appropriate amount of a copyrighted work to take without crossing the fair-use threshold? The legal waters surrounding the creation of composites from pieces of copyrighted work are also deep and murky. What is an appropriate type and amount of guidance to give users with questions involving both copyrightable materials and noncopyrightable materials? Quilter wrapped up her assessment of the difficulties in helping users to understand the law by noting that questions related to the use of music are "just problematic."

An interesting development Quilter covered was the push from some groups to create a small claims court for copyright disputes. In 2017, the Copyright Alternative in Small-Claims Enforcement (CASE) Act was introduced as House bill $3945 .{ }^{47}$ The stated purpose of the

47. Copyright Alternative in Small-Claims Enforcement (CASE) Act, H.R. 3945, 115th Cong. (1st Sess. 2017). 
legislation, which was referred to the House Committee on the Judiciary, is to provide a voluntary claims board within the Copyright Office as an alternative dispute resolution forum. Quilter spoke against the creation of such a venue, citing difficulty in determining what the Copyright Office thinks about fair use from a policy perspective, the potential additional layer of expense such a forum could create for those defending against infringement claims, and her experience with specialized courts: they don't usually produce consumer-friendly decisions. Such a move, she argued, would be of little benefit to the development of the law in this area.

At the close of her presentation, Quilter suggested that the issue of statutory damages for violation of copyright law remains the "elephant in the room." An award of statutory damages can have a devastating effect on a creator. Many will refrain from using material in a way that is a likely fair use due to the risk of damages should a court find that the use is not fair. Those who seek to teach others to apply copyright law must also tread carefully because of the very real consequences of infringement.

\section{A Fair Use Safe Harbor for All Creative Works}

Michael C. Donaldson of Donaldson + Calliff, LLP, has been dubbed the "legal Obi Wan Kenobi" by Eddie Schmidt, former president of the International Documentary Association, and "fair use guru" of the documentary film set by the American Bar Association. ${ }^{48}$ Donaldson is recognized for authorship of several important works including "Refuge from the Storm: A Fair Use Safe Harbor for Non-Fiction Works," an extensive law review article about fair use and film. ${ }^{49}$ His firm clears rights for over 200 documentary and narrative films per year.

Donaldson's firm developed a library of non-fiction films, books, and other works that were the subject of litigation, beginning with the two-volume biography of George Washington which was the subject of the 1841 case Folsom v. Marsh. ${ }^{50}$ After

48. Richard Acello, Doc Defender: He's the Fair-Use Guru of Nonfiction Movies, ABA J. (Dec. 2011)

http://www.abajournal.com/magazine/article/doc_defender_hes_the_fairuse_guru_of_nonfiction_movies/[https://perma.cc/4F6T-VFRM].

49. Michael Donaldson, Refuge from the Storm: A Fair Use Safe Harbor for NonFiction Works, 59 J. COPYRIGHT SOC'Y U.S.A. 477 (2012), available at https:// ssrn.com/abstract $=2232284$.

50. Folsom v. Marsh, 9 F.Cas. 342 (C.C.D. Mass. 1841). 
analyzing content in conjunction with court decisions, Donaldson identified patterns that define what constitutes a safe harbor for fair use in non-fiction works; he tested the pattern against over 80 cases tried since 1978 and found that it held up.

The safe harbor is a three-pronged analysis and lays out three elements to a successful fair-use defense for nonfiction films. First, the material must provide a very good illustration of the point the film is making. Second, the filmmaker must only have used the amount of content required to make the point. Finally, the connection between the material used and the point the film is making must be clear to the average viewer. These three elements, flowing from Judge Pierre N. Leval's influential concept of "transformative uses," 51 form a safe harbor that simplifies the statutory four-factor test in non-fiction films.

In Donaldson's practice and experience, the safe harbor essentially eliminates the need to analyze whether a use is commercial or non-commercial; he said there was not a single case in which the outcome hinges on that point. The safe harbor also eliminates the need for analysis of creative versus non-creative works. Finally, he highlighted the importance of the third element of the safe harbor: the relevance of the use must be clear to average viewers, but also to a judge.

Donaldson illustrated the safe harbor with examples from several films for which his firm oversaw rights and clearances. Representatives from Premise Media Corporation approached Donaldson's firm in 2007 to discuss rights for the documentary Expelled: No Intelligence Allowed; they were concerned about the inclusion of a fifteen second excerpt of John Lennon's song "Imagine," for which Yoko Ono holds copyright ("Nothing to kill or die for / And no religion too"). Donaldson applied the safe harbor analysis: the excerpt provided a good (and in fact, the only) illustration of the point being made, and the filmmaker only used what was needed to make the point (two lines of the song). To strengthen the third prong of the safe harbor, that the connection between the material used and the point was clear to the average viewer, Donaldson suggested slight modifications to the film so that the narration referencing the song came immediately before the song clip was played. His law partner, Lisa Califf, also suggested putting the song lyrics on the screen to further solidify the connection. The film excerpt that includes the "Imagine" lyrics can be viewed on Vimeo. ${ }^{52}$

51. Pierre N. Leval, Toward a Fair Use Standard, 103 HARV. L. REV. 1105 (1990).

52. Michael Donaldson, Expelled, Vimeo (March 9, 2018), https://vimeo.com/ album/5010269/video/259376766. 
The filmmakers of Expelled obtained Errors and Omissions Insurance, which included coverage for the use of the song "Imagine." When the film was released nationwide in 2008, Ono sued in the Southern District of New York seeking a preliminary injunction. ${ }^{53}$ The defendants raised a fair use defense, and the court agreed that the inclusion of the music was a fair use. Although the court applied the traditional four-factor fair use analysis, the safe harbor analysis employed by Donaldson demonstrated the strong likelihood that the use would be found to be fair even before litigation commenced. The court denied Ono's request for injunction. ${ }^{54}$

Donaldson also showed several examples from narrative films in which archival footage was cut in with new footage of actors. The film Jersey Boys (2014), a musical crime drama about Frankie Valli and the Four Seasons, includes a clip from The Ed Sullivan Show in which Sullivan introduces the band. ${ }^{55}$

An episode of the Netflix series, The Crown, intersperses archival news footage, including stills of the Duke of Windsor visiting Hitler. ${ }^{56}$ Oliver Stone's feature film, Snowden (2016), replicates scenes and even camera angles from Laura Poitras's documentary Citizenfour $(2014)^{57}$ Donaldson used this last example to illustrate how the safe harbor analysis differs from the traditional four factors. When re-using copyrighted content, neither the amount taken nor the nature of the use (commercial or non-commercial) tend to be dispositive factors. The utility of the re-use and its connection to the meaning of the new work, are of greater weight.

\section{Fair Use Makers and Policy Shapers}

The final panel of the day focused on the current work of artists, academics, archivists, and libraries actively making fair use of copyrighted content. Each of the four panelists described projects in which making a fair use of existing work was and is essential to the completion of the new work.

53. Yoko Ono Lennon v. Premise Media, 556 F. Supp. 2d 310, 316 (S.D.N.Y. 2008). 54. Id. at 328.

55. Michael Donaldson, Jersey Boys, Vimeo, (Feb. 26, 2018) https://vimeo.com/ album/5010269/video/257584878.

56.Michael Donaldson, The Crown, Vimeo, (Feb. 26, 2018) https://vimeo.com/ album/5010269/video/257585253.

57. Michael Donaldson, Snowden-1, Donaldson+Califf, (Feb. 26, 2018) http://www.donaldsoncallif.com/mcdharvard/11snowden-1/; Michael Donaldson, Snowden-2, Donaldson+Califf,(Feb. 26, 2018) http://www.donaldsoncallif.com/ mcdharvard/12snowden-2/; Michael Donaldson, Snowden-3, Donaldson+Califf, (Feb. 26, 2018) http://www.donaldsoncallif.com/mcdharvard/13snowden-3/; Michael Donaldson, Snowden-4, Donaldson+Califf, (Feb. 26, 2018) http:// www.donaldsoncallif.com/mcdharvard/14snowden-4/. 
Rebekah Modrak, Associate Professor at the Stamps School of Art \& Design at the University of Michigan, began by sharing a design project intended to challenge consumer culture by re-creating the Web presence of an existing company to emphasize the ways in which rhetoric and symbolic representations are used to manipulate consumer behavior. The company she chose to parody was Best Made Co., ${ }^{58}$ which markets hand-crafted axes with painted handles. According to the website, a Best Made axe is "a tool for survival and productivity and at its heart it's a symbol of many admirable virtues." 59 In late 2013, she created an online installation titled Re Made Co., which she describes as follows:

I recreate published reviews of the Best Made store and products, substituting "plunger" for "axe," along with other minor, though significant, alterations to the original articles. The goal is that these fictional articles use the authoritative language of the mainstream media to critique their own failures: the glorifying of a group of white upper-middle-class men sharpening their axes, without any discussion of race, class, gender, and the cultural appropriation of labor. ${ }^{60}$

The critique is powerful in great part because it relies on replication of the complete imagery and language employed by Best Made Co. in advertising their own products (See Figure 8).
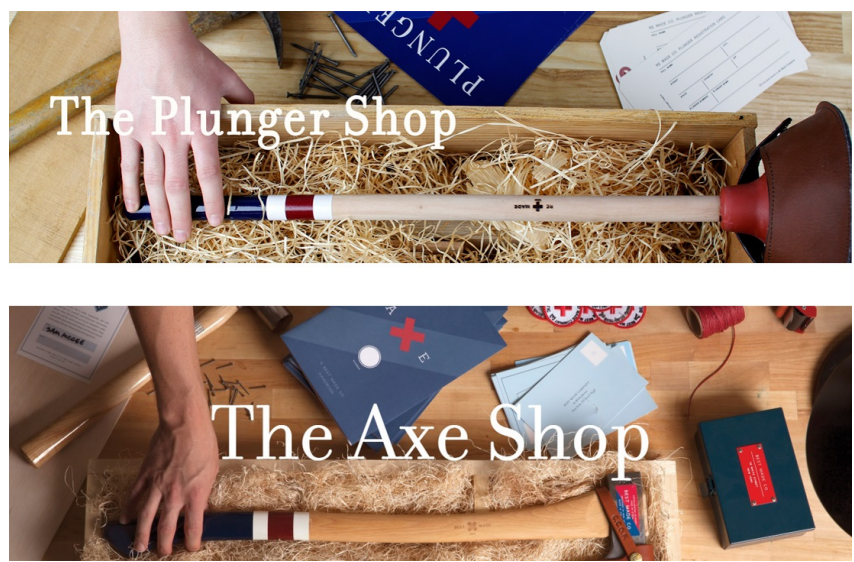

Figure 8. Images from the websites of Modrak (top) and Best Made Co. (bottom). Retrieved from https://www.bestmadeco.com/ and http://remadeco.org.

58. Best Made Co., https://www.bestmadeco.com (last visited July 25, 2018).

59. Best Made Co. FAQ \& Contact, https://www.bestmadeco.com/faq (last visited July $25,2018)$.

60. Re Made Co. Project Description, http://rebekahmodrak.com/project/re-made-co/ (last visited July 25, 2018). 
In the Spring of 2014, Modrak and General Counsel for the University of Michigan received a cease-and-desist letter from the attorney for Best Made Co. The Best Made Co. demanded that Modrak take down the Re Made Co. website and cease all use of the images and language from the Best Made Co. site. The cease and desist letter, available on Modrak's site, ${ }^{61}$ carefully and faithfully reproduced a list of the ways in which her work used the content of Best Made's site to create her commentary. General Counsel for the University of Michigan championed Modrak's work, emphasizing her first amendment right to create the art. Working with university counsel, Modrak made some relatively minor changes to her site to clarify its function as a vehicle for social commentary, though the vast majority of the artwork remains as she originally envisioned it. Modrak credits the University's support and the protection of fair use with her ability to keep the Re Made Co. site ${ }^{62}$ live and continue to use the platform for comment and criticism on consumer culture.

Professor Modrak's work is such an extraordinary example of the utility and value of fair use in creating social commentary that the program's coordinators collaborated with her to create a circular patch, available to attendees, featuring the plungers from Re Made Co., the Harvard logo, and bearing the words Fair Use.

The second project described in the session was from the artist, writer, and activist, Zena Agha. The project, entitled The Place that is Ours: Maps of Palestine-Israel, ${ }^{63}$ was developed in 2017 when Agha accepted a summer fellowship at the Library Innovation Lab at the Harvard Law School. She used materials from the Harvard Map Collection to trace representations of Palestinian and Israeli territory in the space between the Jordan River and the Mediterranean Sea throughout the 20th century. Agha describes her work as something which seeks to "demonstrate the fractured cartography of the region: from place names to border delineations." ${ }^{4}$

Reproducing maps of the region in their entirety, Agha shows the changes in place names and territories over time, with 1948 providing the starkest change due to the partition of Palestine. One particularly

61. Cease and desist letter, https://rebekahmodrak.files.wordpress.com/2017/11/ cease_desist.pdf [https://perma.cc/M592-M6GF] (last visited July 25, 2018).

62. Re Made Co., http://remadeco.org/ (last visited July 25, 2018).

63. Zena Agha, Mapping Palestine-Israel, https://zenaagha.com/projects/mappingpalestine-israel/ [https://perma.cc/69LZ-LLA2] (last visited July 25, 2018).

64. Id. 
powerful element of her project focused on two towns in which her father lived. Both towns appeared in the maps in the early part of the century but disappeared following the partition. The towns themselves had been destroyed, and Agha used both the map images and photographs from her visit to the region to breathe life into a story of the region and its people.

Like Modrak's work, The Place that is Ours relies on the use of existing copyrighted material in its entirety, including the images and text from the map collections held at Harvard. Because her message is conveyed by the differences in the documents themselves, Agha relied on the protection of fair use to copy and display the maps in the presentation of her work and on her website. Agha was seeking to illuminate the political context of map-making in this project, which she describes as ongoing.

Brandon Butler, Director of Information Policy for the University of Virginia Library, began his portion of the panel discussion by explaining the necessity for and obstacles to the preservation of software and the role fair use may play in allowing for such preservation. Rather than focusing on a specific preservation project, Butler's commentary illuminated the challenges that any individual or entity faces when undertaking the archival preservation of a piece of software in its entirety.

Butler first reflected on the need for software preservation, quoting Jeff Rothenberg's 1999 article entitled "Ensuring the Longevity of Digital Information:" “[D]igital information lasts forever -or five years, whichever comes first." ${ }^{2}$ This simple statement encapsulates one of the primary challenges to the long-term preservation of software and other born-digital works, the fragile and ever-changing media in which those works exist. Tapes, floppy disks, and CD-ROMs are only a few of the media that are degrading faster than they can be preserved. It is the almost-ephemeral existence of software that is driving preservation work. Preservation efforts are an outgrowth of the understanding that software both reflects and shapes culture, and that we as a society have become extraordinarily dependent on it in almost every area of modern life.

Beyond the fragility of the media in which software exists, Butler articulated several other non-legal challenges to broad-based preservation. The sheer volume of software that exists, and the rate at

65. Jeff Rothenberg, Ensuring the Longevity of Digital Information, (Feb. 22, 1999), http://www.clir.org/wp-content/uploads/sites/6/ensuring.pdf [https://perma.cc/ Z3LD-6U5H]. 
which new software is created, means that there is an extraordinary amount of material in need of archiving. The industries that produce software are also quite volatile. Very few companies produce and update software long term, entities creating software in siloed spaces may not consider long-term compatibility issues, and new versions of software and updated hardware may effectively brick older versions of programs. Butler also noted that the uneven distribution of resources and expertise among those trying to preserve this material may yield imperfect or incomplete archival collections.

There are, of course, great opportunities in this area. Butler pointed to some of the projects of the Software Preservation Network (SPN), an organization devoted to preservation efforts that ensure long-term access to software. ${ }^{66}$ Of particular interest is the Legal \& Policy Working Group of the SPN, which "supports SPN's goal to explore and document fair use, licensing and information policy specifics pertaining to the lawful preservation, sharing and reuse of software in cultural heritage and research contexts." ${ }^{67}$ Projects such as shared, remote access to emulation products and other efforts designed to raise awareness of the urgency of these preservation initiatives are part of the work that SPN and other similar organizations are undertaking.

After providing some context for the work being done in software preservation, Butler discussed the current state of copyright law with respect to software. Under 17 U.S.C. $\$ 102(b)$, there is very thin protection for software, extending only to the non-functional, expressive elements rather than the ideas, algorithms, and processes involved. However, the act of preservation necessarily involves the copying of the complete works verbatim. It is also likely to include the distribution, display, and performance of the entire work. Butler made clear that this was copyright-regulated activity, and as such there needs to be an account of why this activity is non-infringing. He noted that some limited exceptions for software can be found in the Copyright Act, but that none adequately covers preservation efforts. Section $117^{68}$ limits software back-up copies to those made for personal archival use, and Section $108^{69}$ has limits for digital copies that preclude providing broad access.

Despite these statutory hurdles, Butler noted two potentially useful avenues. Licensing of software for the purpose of preservation may not be

66. Software Preservation Network, http://www.softwarepreservationnetwork.org/ (last visited July 25, 2018).

67. Software Preservation Network Working Groups, http://

www.softwarepreservationnetwork.org/working-groups/[https://perma.cc/9BNPCJGU].

68. 17 U.S.C. $\$ 117$ (2012).

69. 17 U.S.C. $\$ 108(2012)$. 
as difficult as once thought. Creators and owners have some incentive for their creations to live on, and successful models for licensing in the service of preservation do exist. Additionally, new exemptions to the DMCA may provide some flexibility in preservation work, such as changes to the regulations promulgated under the DMCA in 2015 allowing for copying of software from lawfully acquired video games when that software is deemed to have been abandoned. ${ }^{70}$

Despite the complex context in which those preserving software find themselves, Butler argued that fair use offers a genuine opportunity for hope. He suggested that language in the legislative history for the Copyright Act of 1976 favors preservation activities, and that such language could be used to support archival efforts. Moreover, with the increased influence of transformative use in the fair use analysis, there is a story that can be told about the transformative nature of the preservation work being undertaken. Until the law expressly recognizes the legitimacy of copying in the service of preservation, transformative use may provide some safety net for those engaged in the work.

While he recognized that fair use may offer some legal framework for preservation, Butler ultimately advocated for a threepronged approach to reconciling copyright law with software preservation efforts. He called for best practices in the preservation process to be articulated and shared, for work toward a DMCA exemption that explicitly recognizes the value and importance of software preservation and permits such work, and for licensing for the purpose of preservation to be actively pursued.

The final panelist of the afternoon was David Hansen, then Director of Copyright and Scholarly Communication at Duke University. Hansen explored the intersection of the first sale doctrine and fair use analysis in controlled digital lending projects, specifically the project undertaken by Duke. ${ }^{71}$ To provide some context for the project, Hansen articulated some of the changes seen in library use in the last few decades. He posited that people are actively using the

70. For an extensive discussion of the considerations relevant to the promulgation of this regulation, see Exemption to Prohibition on Circumvention of Copyright

Protection Systems for Access Control Technologies, 80 Fed. Reg. 65944 (Oct. 28, 2015)

(to be codified at 37 C.F.R. pt. 201).

71. For excellent overviews of the copyright implications of controlled digital lending projects, see David R. Hansen \& Kyle K. Courtney, A White Paper on Controlled Digital Lending of Library Books, LAWARXIV (Sep.24, 2018), osf.io/preprints/ lawarxiv/7fdyr, and Michelle M. Wu, Piece-by-Piece Review of Digitize-and-Lend Projects through the Lens of Copyright and Fair Use, 36 LEG. REF. SVCS. Q. 51 (2017). 
physical space and the electronic resources provided by libraries, but that use of physical books has dramatically decreased. With this change in use many libraries, Duke included, are moving some of their physical materials off site. Hansen presented an infographic summarizing both the resources and services of the Duke libraries to further contextualize the controlled digital lending project. With a total volume count of over 7,000,000 and more than 59,000 linear feet of manuscripts and archives, Duke saw only slightly more than 300,000 total circulations of books and other items in a single year. During that same year, students printed almost $6,000,000$ pages on Duke library printers.

With this picture in place, Hansen turned to a discussion of a fundamental library service. Libraries lend books. The first sale doctrine, codified in Section 109 of Title 17 of the United States Code, articulates the clear right of one who purchases a lawful copy or phonorecord to sell or dispose of that copy in whatever way that person sees fit. ${ }^{72}$ It is the first sale doctrine that secures to libraries the right to lend. In discussing the importance of the first sale doctrine, Hansen offered a quote from Kirtsaeng v. John Wiley \& Sons, Inc., a 2013 Supreme Court decision: "The 'first sale' doctrine is a common-law doctrine with an impeccable historic pedigree."73

Hansen then described Duke's controlled digital lending project and looked at the way in which the first sale doctrine does (or does not) apply. At its most fundamental, the project allows for the circulation of a digitized title in place of a physical title in a controlled manner, such that the number of copies owned by the library and the number of copies loaned by the library are always in a one-to-one ratio. The library can never lend more copies than it has legitimately acquired, whether through purchase or donation. Where a library has one copy of a print book and makes a digital copy of that book, the library can circulate only one copy of the book at a time, regardless of format. The project also includes appropriate technological measures to prohibit a borrower from retaining a permanent copy of the book or distributing additional copies.

This controlled digital lending model clearly requires that the library make a copy of the work they wish to lend digitally. This begs the question whether the first sale doctrine should account for technological advancements that allow copying for format shifting, retaining the underlying transaction of the loan in which libraries have been engaged for years, though admittedly creating a copy of the work. 
Hansen noted that Section 109 specifically references the public distribution and display of a "particular copy" of a lawfully made work, but again questioned whether that language stands in opposition to the controlled digital lending model Duke has created.

Rather than focusing solely on the rights afforded by the codification and common-law application of the first sale doctrine, Hansen asked how first sale and fair use might work together to cover controlled digital lending. He applied the four factors essential to a fair use analysis to the project and challenged attendees to consider how this type of lending might be considered a fair use. For the first factor, the purpose and character of the use, Hansen noted that the library's copying would be for research and education. While libraries cannot ascertain the purpose and character of the downstream use of the material by borrowers, he suggested that a fair use analysis ought not to be conditioned on the nature of a borrower's use. The library's copy is certainly made for noncommercial purposes, and the controlled nature of the project in preserving the one-to-one ratio of copies loaned to owned fulfills the promise of the first sale doctrine. $\mathrm{He}$ completed his discussion of the first factor by noting that use a library is making is not transformative, an important point given the emphasis on transformative use in more recent jurisprudence.

For the second factor, the nature of the copyright work, Hansen reflected on Crews's keynote address and his discussion of the diminishing importance of the second factor in contemporary fair use analysis. He suggested that regardless of the strength of the second factor in the analysis, libraries can make choices in controlled digital lending to focus primarily on factual and scholarly works rather than highly creative works. Since a large portion of major research library collections have a scholarly focus, the use of these works may give libraries an advantage in the second factor inquiry. Finally, Hansen suggested that a focus on orphaned works and out-of-print works for a controlled digital lending project might offer the most advantageous second factor analysis.

The third factor asks that we examine the amount of the original work used. In the current project, the whole work is necessarily copied. Hansen argues that the use of the whole work is reasonable in light of the intended use. There is precedent showing 
that the use of an entire work may be appropriate depending on the proposed use, and this precedent may strengthen the fair use argument for libraries engaged in controlled digital lending. Additionally, Hansen asked whether this third factor might have a temporal component-whether temporary rather than permanent access to the copy tempers the analysis.

Finally, he discussed the fourth factor, the effect of use on the market. This factor offers the greatest degree of complexity regarding controlled digital lending. An essential first question must be considered: what is the market? Hansen identified language from the 2018 TVEyes case ${ }^{74}$ to clarify the question. He asked if we should contemplate "traditional, reasonable, or likely to be developed markets," or if we should instead focus on "plausibly exploitable markets." $75 \mathrm{He}$ admitted that it is likely that controlled digital lending may have some negative impact on publishers' markets, but countered that the act of lending physical books might have a similar negative impact. He reminded attendees that fair use jurisprudence has long recognized that not all market harms are cognizable copyright injuries.

As he summed up his presentation, Hansen suggested additional questions for further consideration. How should the fair use analysis change for this project if publishers are already making available digital copies of the books that libraries want to include in their project under the same, or similar terms? And how might the analysis change if controlled digital lending were undertaken by a commercial entity rather than by a library? Though Hansen did not explore these questions further in the presentation, he provided a valuable opportunity for attendees to reflect following the program.

\section{A Fair Day Out}

"Tried and True: Fair Use Tales for the Telling" featured a diverse cast of fair users-academics, librarians, artists, and attorneys. It was particularly valuable for us, as librarians, to see the fair use doctrine applied in such a variety of settings outside academia. While we learned so much from this delightful day, our primary takeaway was that fair use is a strong and flexible doctrine that allows creativity to flourish and new ideas to grow from the fertile ground of existing work. In the future, we expect to see fair use continue to enable works of criticism, commentary, and parody. Further, fair use may pave the way for the application of 
technology in efforts to expand traditional library services, especially lending and preservation. And perhaps, in the not-too-distant future, we can benefit from a quick poll of experts to find an answer to the compelling question: "Can I fair use it?" 